\title{
Evaluation of PV, Wind, Diesel Hybrid Energy Potential for GSM Tower in Myanmar
}

\author{
Zin Mar Nyo \\ Departementof Electrical Power Engineering, Mandalay Technological University, Myanmar
}

\begin{tabular}{|c|c|}
\hline Article Info & ABSTRACT \\
\hline Article history: & Not only GSM, WCDMA but also CDMA technology can be used in \\
\hline Received May 28, 2015 & $\begin{array}{l}\text { Myanmar but GSM pre-dominates in the market. There are over million } \\
\text { unique subscribers across the country in } 2013 \text {. Power supply for telecom }\end{array}$ \\
\hline Revised Jul 14, 2015 & becomes main challenges in Myanmar where the electricity can not access in \\
\hline Accepted Aug 6, 2015 & $\begin{array}{l}\text { rural area. To minimize deficit of power, the government has set a target to } \\
\text { covert some of tower sites to renewable solutions by } 2015 \text {. This paper }\end{array}$ \\
\hline Keyword: & $\begin{array}{l}\text { proposes the use of a PV, wind and diesel generator hybrid system with } \\
\text { storage element in order to determine the optimal configuration of renewable }\end{array}$ \\
\hline Hybrid & energy in Myanmar. This paper discusses the development of a renewable \\
\hline Photovoltaic & $\begin{array}{l}\text { energy sources (RES) that can be used for electric power supply of } \\
\text { GSM base station site at any given time and considers the feasibility }\end{array}$ \\
\hline Rural areas & of developing Solar (photovoltaic)-Wind-Diesel hybrid power systems \\
\hline Solar energy & for supplying electricity to off-grid rural telecommunication. The Hybrid \\
\hline Wind energy & $\begin{array}{l}\text { Optimization Model for Electric Renewables (HOMER) was used to } \\
\text { simulate and generate feasible solution through combinations of } \\
\text { photovoltaic, Wind Turbines and Diesel Generator with a minimum } \\
\text { levelised cost of electricity supply and to determine the technical } \\
\text { feasibility of the system. }\end{array}$ \\
\hline
\end{tabular}

Copyright (C) 2015 Institute of Advanced Engineering and Science. All rights reserved.

\section{Corresponding Author:}

Zin Mar Nyo,

Departementof Electrical Power Engineering,

Mandalay Technological University, Myanmar

Email: zinmarnyo.pku@gmail.com

\section{INTRODUCTION}

Myanmar has very intermittent renewable sources. It mentions that wind generation system may not be currently economically attraction. Nevertheless, it would be useful for potential hybrid situations such as remote area. On the other hand, generally $70 \%$ of the population lives in rural areas which are not commonly use electricity. In fact, this paper hands out hybrid system combination diesel generators with battery, converter subsystems in the usage of rural telecommunication, Myanmar. The hybrid system design was investigated depending on factors such as consumer requirement, site location, and system economic in the proposed area, Pathein. The purpose of this paper is not only to develop renewable energy usage in Myanmar but also to provide electricity for rural telecommunications which couldn't access to connect to the national grid in the remote area, Myanmar. Solar, wind and hybrid systems with battery backup for energy storage are the most cost effective reliable solution to power for telecommunication site in remote areas. The off-grid network in Myanmar is expected to grow from 540 sites in 2013 to 2850 sites by 2015 based on current network rollout plans by mobile operators. The economic feasibility of the case study area, Pathein is determined by HOMER model imputed from existing data: such as local status and resource availability. The selection component of PV-wind-diesel hybrid system is apparatus based on optimal design. To ensure the feasibility target of this project, electrical demand for telecommunication in rural area and socio-economic development are provided, at the sametime, additional benefits of this project are to reduce carbon dioxide and particulates entering into the atmosphere. 


\section{RENEWABLE ENERGY IN MYANMAR}

Myanmar is situated in the south eastern part of the Asian continent. It enjoys abundant sun shine all year round, especially in the Central Myanmar Dry Zone Area. Myanmar has vast measure of renewable energy resource in various kinds. Solar, Hydro, Wind and Biomass are at great potential to utilize easily for the benefit of the poor to fulfill their basic needs of fuel for cooking and lighting in rural area. Among them, wind pattern in Myanmar is generally not regular and low in capacity to produce sustainable energy at the current availability of technology. Potential available solar energy of Myanmar is around 51973.8TWh per year. Myanmar Electric Power Enterprise experimental measurement indicated that irradiation intensity of more than $5 \mathrm{kWh} / \mathrm{m}^{2}$ /day was observed during the dry seasons New Energy and Industrial Technology Development Organization (NEDO) of Japan performed in 1997 a study on renewable energy potential in GMS region and assessed that Myanmar has potentially available Wind Energy of 360.1Wh per year. Promising areas to harness wind energy are in three regions, namely Hilly Regions of Chin and Shan states, Coastal regions in the south and Western part of the country and central part of Myanmar. General observation shows that wind power potential in Myanmar is relatively low and irregular. There is a considerable measurement of stagnant period which occur even in generally windy areas. Solar power is found to be a most potential one to hybrid with wind power in Myanmar [08Win].



Figure 1. Yearly average insolation in Myanmar [08 Win]

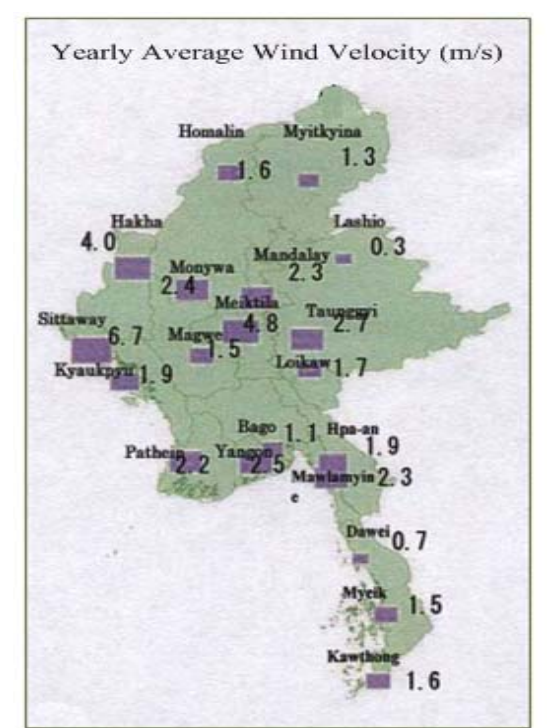

Figure 2. Yearly average wind speed in Myanmar [08 Win]

\section{PROPOSED SITE LOCATION FOR CASE STUDY}

In order to assess the viability of wind or solar powered systems, information must be gathered on the resourceusually obtained locally. The cost of hybrid systems is currently high compared to conventional diesel minigrid systems. However, as it is typical for emerging technologies and markets, system design and industry structure will continue to evolve in concert with the growth in demand, technology development funding, and costs which can be expected to decrease significantly. In this study was performed for Pathein, Ayeyarwady Division. The geographical location of Pathein is located between North Latitude of $16^{\circ} 48^{\prime}$ and East Longitude of $94^{\circ} 42^{\prime}$. The daily average of wind speed and sun shine hour is recorded from this proposed site as shown in Table 1. The proposed hybrid system is intended for supplying electricity to telecommunication of this proposed site. Based on NASA data, afeasibility study for PV-wind-diesel hybrid system at Pathein is prepared to optimal design model for telecommunication system in this paper. 
Table 1. Parameters of Solar and Wind data for proposed site

\begin{tabular}{ccc}
\hline Month & Solar $(\mathbf{K W h} / \mathbf{m} \mathbf{2} / \mathbf{d})$ & Wind $(\mathbf{m} / \mathbf{s})$ \\
\hline January & 5.47 & 2.2 \\
February & 6.16 & 2.2 \\
March & 6.78 & 2.3 \\
April & 6.83 & 2.3 \\
May & 5.23 & 2.7 \\
June & 3.43 & 4.3 \\
July & 3.45 & 3.9 \\
August & 3.20 & 4.1 \\
September & 4.10 & 2.7 \\
October & 4.84 & 2.2 \\
November & 4.95 & 2.6 \\
December & 5.16 & 2.5 \\
\hline
\end{tabular}

\section{HYBRID SYSTEM COMPONENTS}

The hybrid system after the prefeasibility study consists of the following components:

1) KYOCERA (KD 250 GX-LFB2)

2) BWC Excel-S wind turbine

3) Cellcube FB 20-40 battery

4) Converter.

5) Diesel generator

6) GSM Load.

\subsection{Photovoltaic Module}

Kyocera (kd 250 gx-lfb2) photovoltaic panel is considered in the scheme, with initial capital cost $2000 / \mathrm{kW}$ and $\mathrm{O} \& \mathrm{M}$ cost $\$ 50 / \mathrm{yr}$ with rated power $250 \mathrm{Watt}$ and rated voltage $29.8 \mathrm{~V}$. Its lifetime is estimated at 20 years.

\subsection{Wind Turbine}

In this study, Pathein Wind Power is considered BWC Excel-S model. It has a rated capacity of 10 $\mathrm{kW}$ AC as an output. Its initial cost is $\$ 28895$, replacement at $\$ 2000$ and O \& M cost is \$50/yr.

\subsection{Battery}

The batteries must be suitable to withstand the heavy daily cycling required for this application. From the datasheet given by HOMER software, the minimum state of charge of the battery is $40 \%$.Its round trip efficiency is $80 \%$. Cellcube FB 20-40 battery is selected for this study. Cellcube FB 20-40battery models (48V, 833Ah). The capital cost is \$ 800/batt and O \& M cost is \$30/yr.

\subsection{Converter}

Converter is used which can work both as an inverter and rectifier depending on the direction of low of power. In the present case, the size of the converter used is $9 \mathrm{~kW}$ for simulation purposes. Its initial cost is $\$ 900 / \mathrm{KW}$ and its replacement cost is $\$ 800 / \mathrm{kW}$ and O \& M cost is $\$ 20 / \mathrm{yr}$.

\subsection{Diesel Generator}

Diesel generator technology is wide spread and the development of the power plant is relatively easy. The diesel back-up system is operated at times when the output from wind, hydro and solar systems fails to satisfy the load and when the battery storage is depleted. The size of diesel generator is $2 \mathrm{~kW}$. The initial cost and replacement cost are respectively (\$700, \$600), O \& M cost is of $0.001 \$ / \mathrm{hr}$.

\subsection{Power Consumption Load for GSM}

This paper indicates the approximate power consumption for telecommunication system is $29 \mathrm{kWh} /$ day with $2.4 \mathrm{~kW}$ peak and the system runs on $48 \mathrm{~V}$ DC bus. There is a constant load of telecom equipment's work for 24 hours in a day. The daily load power consumption is $42.01 \mathrm{kWh} /$ day. Total power consumption of GSM (Global System for Mobile Communications) load is 29640 Watts. To provide uninterruptable service and therefore these sites require continuous power throughout the year, therefore, the hourly load is almost a constant, as the power consumption remains the same. Telecommunication monthly load profile is shown in Figure 3 which is produced by HOMER software. Table 2 shows the power consumption of $800 \mathrm{~W} / 900 \mathrm{MHz}$ GSM/UMTS dual mode. In this configuration, Base band Processing board type C (BPC), Universal Base band Processing board for GSM (UPBG), Circuit Switching Call (CS) are 
included. Radio Mode GSM (Global System for Mobile Communications)/UMTS (Universal Mobile Telecommunication System) are used for telecommunications system in Pathein, Ayeyarwady Division.

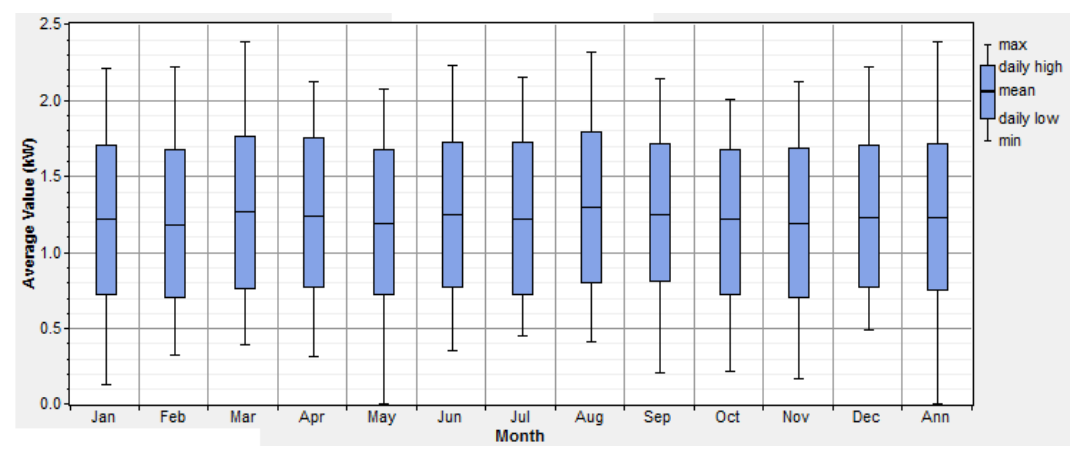

Figure 3. Monthly load profile for GSM tower

Table 2. Power Consumption for GSM/UMTS

\begin{tabular}{cc}
\hline Configuration & Power Consumption $(800 \mathrm{~W} / 900 \mathrm{MHz})$ \\
\hline 6CS + 12TRX/1BPC+1UBPG & $95 \mathrm{~W}$ \\
12CS + 24TRX/2BPC+2UBPG & $145 \mathrm{~W}$ \\
GSM S1 + 1UMTS CS & $300 \mathrm{~W}$ \\
GSM S2+ 1UMTS CS & $245 \mathrm{~W}$ \\
GSM S3 + 1UMTS CS & $235 \mathrm{~W}$ \\
GSM S4 + 1UMTS CS & $215 \mathrm{~W}$ \\
Total Power Consumption & $1235 \mathrm{~W}$ \\
\hline
\end{tabular}

\section{WIND AND SOLAR RESOURCES}

The annual average wind speed and the annual average insolation level at Pathein are $5.29 \mathrm{~m} / \mathrm{sand}$ $5.71 \mathrm{kWh} / \mathrm{m}$ 2/day, respectively. The monthly wind speed variation is shown in Figure 4. The monthly clearness index and the daily radiation are shown in Figure 5.

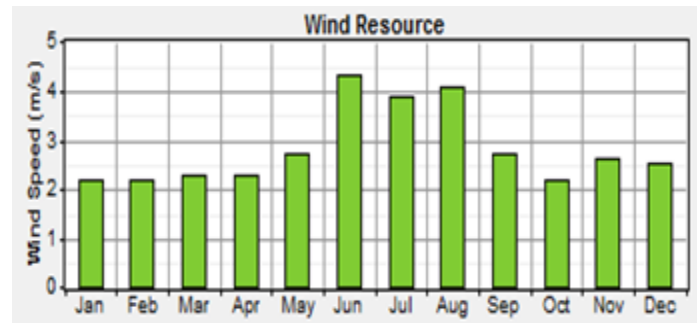

Figure 4. Wind speed for proposed site by using HOMER

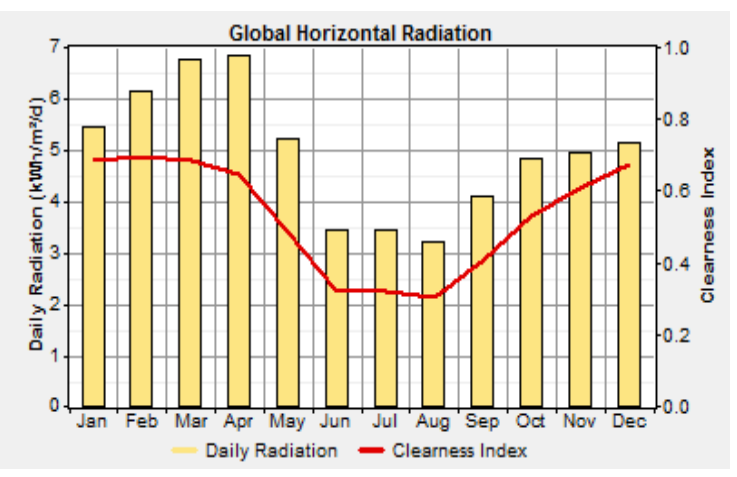

Figure 5. Daily radiation and clearness index for proposed site by using HOMER

\section{HYBRID SYSTEM WITH HOMER SOFTWARE}

HOMER software simulates the operation of the proposed system along the year by making an energy balance between the generation and the load to determine the feasible system architecture which meet the load demand under the site condition beside specifying the cost-effective combination based on the total net present cost [TNPC] which is the summation of all the costs and revenue all over the project life time which is assumed 25 years.

Numbers of combinations are to be considered as follows:

1) Wind turbine, Batteries and Diesel generation. 
2) PV panel, Batteries and Diesel generation.

3) Wind turbine, Batteries and PV panels.

4) Wind turbine, Batteries, PV panels and Diesel generation.

Then simulated using HOMER software to determine the most optimum combination for telecommunication load.

\subsection{Wind and Diesel Generation}

Figure 6 shows Wind and Diesel system design using HOMER. The simulation results present the optimum combination: two $10 \mathrm{~kW}$ AC wind turbine, $2 \mathrm{~kW}$ generator, 20 batteries and $10 \mathrm{~kW}$ converter. In this work, the amount of possible pollutants arising from the use of diesel fuel in powering the GSM Base Station Site was simulated with HOMER software. Wind and Diesel have total net present cost of \$187625, operating cost of $\$ 3914 / \mathrm{yr}$, and the levelized cost of energy of $\$ 1.368 / \mathrm{kWh}$ as shown in Table 3. Excess electricity for this combination is $8.46 \mathrm{kWh} / \mathrm{yr}(0.07 \%)$.



Figure 6. Wind and diesel electric production

\section{2. $P V$ and Diesel Generation}

The Figure 7 shows PV and Diesel system design using HOMER. The simulation results present the optimum combination: 10kW PV, $1 \mathrm{~kW}$ Diesel Generator, 10 battery unit and 10kW Converter. Photovoltaic/Diesel /Battery has total net present cost of $\$ 102775$ operating cost of \$886/yr, and the levelized cost of energy of $\$ 0.749 / \mathrm{kWh}$ as shown in Table 3. Excess electricity for this combination is $2872 \mathrm{kWh} / \mathrm{yr}$ $(17.6 \%)$.

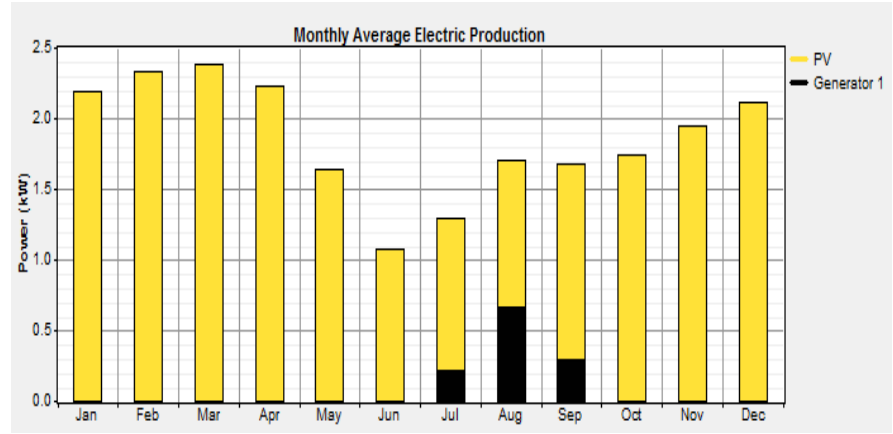

Figure 7. PV and diesel electric production

\subsection{PV and Wind}

Figure 8 shows PV and Wind system design using HOMER. The simulation results present the combination: $10 \mathrm{~kW}$ PV, one $10 \mathrm{~kW}$ AC wind turbine, 10 battery unit and $10 \mathrm{~kW}$ converter. PV and Wind have total net present cost of $\$ 135282$, operating cost of $\$ 1196 / \mathrm{yr}$, and the levelized cost of energy of $\$ 0.986 / \mathrm{kWh}$ as shown in Table 3. Excess electricity for this combination is $4760 \mathrm{kWh} / \mathrm{yr}(26.5 \%)$. 


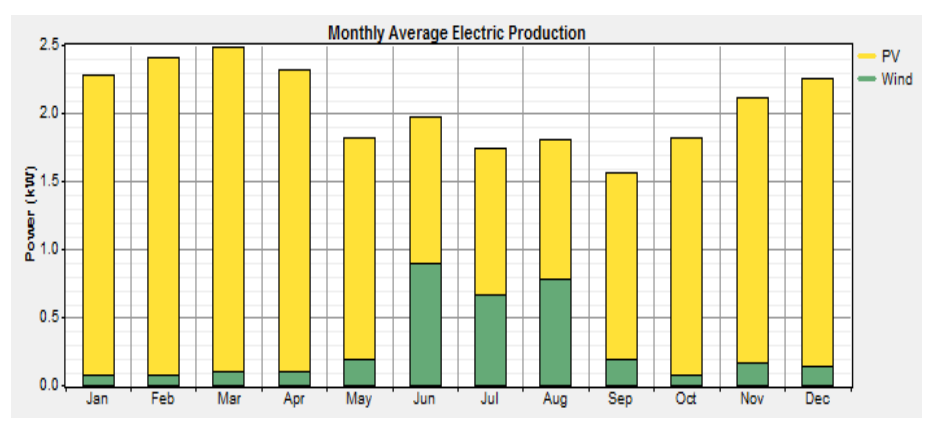

Figure 8. PV and Wind electric production

\subsection{PV, Wind and Diesel}

The Figure 9 shows PV, Wind and Diesel system design using HOMER. The simulation results present the optimum combination: $10 \mathrm{~kW} \mathrm{PV}$, one $10 \mathrm{~kW}$ AC wind turbine, $1 \mathrm{~kW}$ generator, 10 battery unit and $10 \mathrm{~kW}$ converter. Photovoltaic/Wind/Diesel has total net present cost of \$135564 operating cost of \$1191/yr, and the levelized cost of energy of $\$ 0.988 / \mathrm{kWh}$ as shown in Table 3. Excess electricity for this combination is $4760 \mathrm{kWh} / \mathrm{yr}(26.5 \%)$.

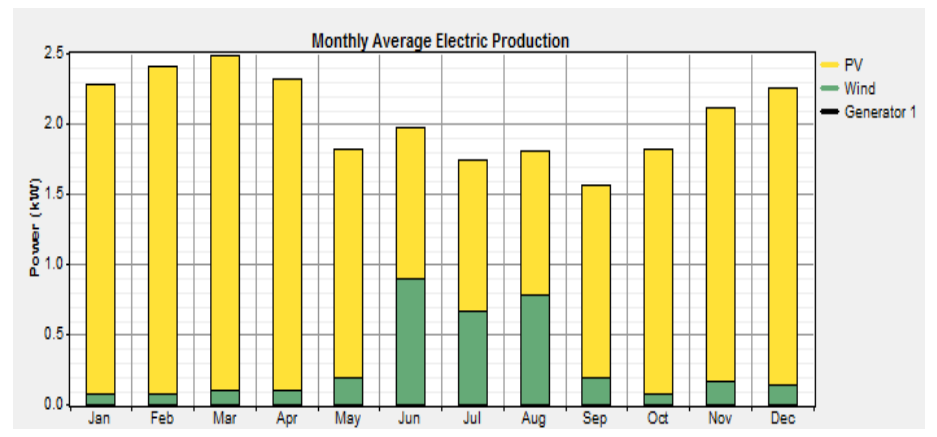

Figure 9. PV, wind and diesel electric production

\section{OPTIMIZATION RESULTS}

The combination of energy system components are $7 \mathrm{~kW}$ PV-Array, 2kW Diesel Generator, 3x833Ah and 9kW Conveter. The hybrid system combination are simulated with their costing and sizing compared with a PV/wind/battery/diesel system. It can be seen from the simulation results in Table 3. It can meet the demand requirements cost effectively. From the optimization results, the best optimal combination of energy system components are 10kW PV-Array, 1kW Diesel Generator, 10x833Ah and 10kW Converter. In this work, the amount of possible pollutants arising from the use of diesel fuel in powering the GSM tower was simulated with HOMER software. PV/Diesel/Battery has total NPC of \$102775, operating cost of $\$ 886 / \mathrm{yr}$, and the levelized cost of energy of $\$ 0.749$ per $\mathrm{kWh}$ as shown in Table 3.

Table 3. Comparison Results of Different Combinations

\begin{tabular}{ccccc}
\hline Description & $\begin{array}{c}\text { Case } \\
\text { Study I } \\
\text { Wind } \\
\text { and Diesel }\end{array}$ & $\begin{array}{c}\text { Case } \\
\text { Study II } \\
\text { PV and Diesel }\end{array}$ & $\begin{array}{c}\text { Case } \\
\text { Study III } \\
\text { PV and Wind }\end{array}$ & $\begin{array}{c}\text { Case } \\
\text { Study IV } \\
\text { PV, Wind } \\
\text { and Diesel }\end{array}$ \\
\hline Total Net Present Cost $(\$)$ & 187625 & 102775 & 135282 & 135564 \\
Levelized Cost of Energy $(\$ / \mathrm{kWh})$ & 1.368 & 0.749 & 0.986 & 0.988 \\
Operation Cost $(\$ / \mathrm{yr})$ & 3914 & 886 & 1196 & 1191 \\
Excess Electricity $(\mathrm{kWh} / \mathrm{yr})$ & $8.46(0.07 \%)$ & $2872(17.6 \%)$ & $4760(26.5 \%)$ & $4760(26.5 \%)$ \\
PV array $(\mathrm{kWh} / \mathrm{yr})$ & & $15411(95 \%)$ & $15411(86 \%)$ & $15411(86 \%)$ \\
Wind turbine(kWh/yr) & $5.063(40 \%)$ & - & $2531(14 \%)$ & $2531(14 \%)$ \\
Generator $(\mathrm{kWh} / \mathrm{yr})$ & $7490(60 \%)$ & $876(5 \%)$ & - & - \\
CO2 Emission $(\mathrm{kg} / \mathrm{yr})$ & 6511 & 848 & - & - \\
Fuel Consumption $(\mathrm{L} / \mathrm{yr})$ & 2473 & 322 & - & - \\
\hline
\end{tabular}

IJECE Vol. 5, No. 6, December 2015 : 1245 - 1251 


\section{CONCLUSION}

In hybrid Photovoltaic/Diesel/Battery system, the Photovoltaic system supplies 95\% of the annual electricity production. Diesel generator contributes $5 \%$ of the total electricity and the excess electricity is $17.6 \%$, respectively. Total net present cost, energy cost and operation cost are less than other combination system. Therefore Case II is chosen as the best optimal design for telecommunications system. The selected optimum combination is sized to meet the power consumption of telecommunication system for about $100 \%$ availability. The given load characteristic and diesel generator a methodology, which uses the site-climatic conditions, is developed to calculate the optimum mix of the system components. The optimum design of this system is based on: a pre-defined load pattern to be supplied; the pertinent weather data; the relevant market prices; and the applicable recent economic rates (diesel-battery hybrid system). It is generally a viable option for off-grid area of Pathein Region, Myanmar. This paper, one solution, is to use combinations of renewable and conventional power technologies, or hybrid systems, to provide electricity for telecommunication in offgrid areas where it is too expensive to extend the grid, or where the grid cannot operate without high losses.

\section{ACKNOWLEDGEMENTS}

Special thanks are offered to Dr. Khin Thuzar Soe, Associate Professor, Department of Electrical Power Engineering, Mandalay Technological University, for her encouragement, constructive guidance and kindly advice throughout the preparation of this paper. The author's special thanks are sent to her parents, U Mg Nyo and Daw Cho Mar, for their guidance and support from childhood till now. And the author would like to convey her gratitude to all persons who were directly or indirectly involved towards the successful completion of this paper.

\section{REFERENCES}

[1] Souissi Ahmed, Hasnaoui Othman, and Sallami Ani, "Optimal Sizing of a Hybrid System of Renewable Energy for a Reliable Load Supply without Interruption,” European Journal of Scientific Research, Vol. 45 No. 4, pp. 620-629, 2010.

[2] Dike U. Ike, Anthony U. Adoghe, and Ademola Abdulkareem, "Analysis of Telecom Base Stations Powered By Solar Energy”

[3] Pragya Nema, Saroj Rangnekar, and R. K. Nema, "Prefasibility Study of PV-Solar/Wind Hybrid Energy System for GSM Type Mobile Telephony Base StationIn Central India,” 2010.

[4] Ani Vincent Anayochukwu, Nzeako, and Anthony Ndubueze, "Energy Optimization at GSM Base Station Sites Located in Rural Areas," 2012.

[5] Amherst, "Renewable Energy Research Laboratory," 2006.

[6] Win Khaing, "Renewable Energy and Rural Development in Myanmar," TCDPAP \& FIDIC/ASPAC Seoul Conference, 2008.

[7] “Myanmar: Energy Sector Initial Assessment”, Available: www.adb.org. [Accessed: June, 2013].

[8] Zeraia Hassiba, Larbes Cherif, and Malek Ali, “Optimal Operational Strategy of Hybrid Renewable Energy System for Rural Electrification of a remote,” Algeria Energy Procedia, 2013.

\section{BIOGRAPHY OF AUTHOR}

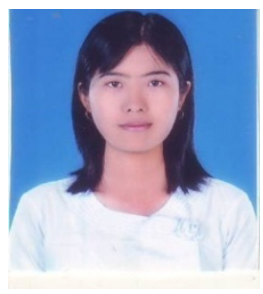

Zin Mar Nyo, she received ME degree in electrical power engineering from Mandalay Technological University. Her research interests are renewable and energy engineering. She is doing Ph.D (Thesis) at Electrical Engineering Department of Mandalay Technological University, Myanmar. Her email address is zinmarnyo.pku@gmail.com. 